\title{
CHARLES ABBOTT DAVIS
}

Mr. Charles Abbott Davis, curator of the Roger Williams Park museum at Providence, R. I., died at the Rhode Island hospital January 28,1908 , from cerebro spinal meningitis.

He was a devoted student of natural history and was particularly interested in entomology and shells. He was a member of many societies, among which were the Entomological Society of America, Aggassiz Association and the Rhode Island Field Naturalists' Society, having organized the latter.

A. F. B.

\section{Reviews}

\section{Studies of Parasites of the Cotton Boll Weevil, by W. DwIGHT} Pierce, U. S. Department of Agriculture, Bureau of Entomology, Bulletin 73 .

Theoretically at least, the best method of controlling an injurious insect is by encouraging its natural enemies. All economic entomologists recognize the value of parasites and predaceous forms as checks upon the multiplication of insect pests, and many have made more or less general recommendations with a view of obtaining the greatest possible assistance from these agencies. Careful studies have been made of the parasites of several of our more important insect enemies such, for example, as the exhaustive study by Dr. Howard, of the parasites of the white marked tussock moth, and a careful investigation by Fiske, of the parasites of the common tent caterpillar. The parasites of the Coccidae, thanks again to the work of Dr. Howard, are relatively well known, and enemies of this group have been successfully introduced into localities and very satisfactorily controlled dangerous outbreaks of their hosts. The bulletin under consideration is specially noteworthy, in that it gives a large amount of accurate data relating to the parasites of an entire group in a faunal area. The investigator has ascertained the sources from whence come the parasites attacking the boll weevil. A study of the biology of the native host forms has shown the possibility of taking advantage of natural conditions within certain limitations so as to force insects, normally subsisting on species of small or no economic importance, to attack one of our most dangerous pests. Such methods can be employed to advantage only after the factors controlling the existence of these forms are thoroughly understood. These studies are a striking illustration of the importance of thorough investigations of an entire group. The author is to be congratulated upon having produced a very valuable and suggestive contribution to economic entomology.

E. P. F.

Report of the Entomological Department of the New Jersey Agricultural College Experiment Station for 1907, by JонN B. SмiтH, pages 389-560.

This publication appears in its usual form, and like its predecessors contains numerous valuable observations upon the more injurious species of the 
year, special studies being made upon root maggots. In reporting upon field tests of insecticides for controlling San José scale, Dr. Smith states that lime-sulphur washes have not gained in favor in New Jersey, though they have fully held their own. He reports good results as being almost invariably obtained when a miscible oil, such as scalecide, is used, and devotes considerable space to the discussion of home made miscible oils. The somewhat extended evidence respecting the application of bands of carbolic acid to trunks of trees is by no means favorable to this method of treatment. Brief notes are given on some new materials which may possibly be used as insecticides; namely, arsenate of iron, arsenate of lime and arsenate of barium.

About half of the report is deservedly occupied by an account of the exceedingly important work against mosquitoes done in 1907. Details are given respecting methods and the amount of work accomplished in different localities. We regret that the author has not seen fit to incorporate in this portion of the report a summarized statement as to what has already been accomplished along this most practical line of effort, so that one can, in a short time, gain an adequate idea of the progress made in freeing New Jersey from the blood-thirsty swarms of mosquitoes. One of the most interesting occurrences of the year was the discovery of the larva and breeding habits of Culex perturbans, a species which up to last year had eluded the vigilance of all Americans working upon the biology of this group.

E. P. F.

\section{Report on the Injurious Insects and Other Animals Observed in} the Midland Counties during 1907 , by Walter E. Collinge, 58 pages.

This report gives summarized accounts of a large number of the more important injurious insects, together with reports on insecticides and fungicides. Experiments in controlling the gall mite on black currant, Eriophyes ribis, show that spraying with the lime-sulphur wash is most effective. Reporting upon a series of experiments for destroying all insects and other injurious organisms inhabiting the soil, Prof. Collinge states that he has obtained a fumigant designated as "Apterite" which will effectually rid the soil of these enemies. This is presumably a proprietary material, as no clue is given respecting its composition. The general appearance of this report is exceedingly good, the letter press and paper being much above the average.

E. P. F.

\section{Current Notes}

\section{Conducted by the Associate Editor}

The Associate Editor will be engaged during the summer in work on predaceous beetles which are being imported to assist in controlling the gypsy moth. After May 1st all communications should be directed to Melrose Highlands, Mass., Care Gypsy Moth Parasite Laboratory, instead of to Washington, D. C.

Graduate School of Agriculture. The preliminary announcement of the 


\section{$2 \mathrm{BHL}$ Biodiversity Heritage Library}

Felt, Ephraim Porter. 1908. "Reviews." Journal of economic entomology 1(2), 165-166. https://doi.org/10.1093/jee/1.2.165a.

View This Item Online: https://www.biodiversitylibrary.org/item/37189

DOI: https://doi.org/10.1093/jee/1.2.165a

Permalink: https://www.biodiversitylibrary.org/partpdf/325851

\section{Holding Institution}

New York Botanical Garden, LuEsther T. Mertz Library

\section{Sponsored by}

The LuEsther T Mertz Library, the New York Botanical Garden

\section{Copyright \& Reuse}

Copyright Status: NOT_IN_COPYRIGHT

This document was created from content at the Biodiversity Heritage Library, the world's largest open access digital library for biodiversity literature and archives. Visit BHL at https://www.biodiversitylibrary.org. 